\title{
MYCOLOGICAL STATUS OF SOME DAIRY PRODUCTES SERVING IN ASSIUT UNIVERSITY HOSPITALS
}

\author{
NAGAH, M. SAAD ${ }^{*}$ and YASSER, S. WAFY** \\ *Professor of milk hygiene, Faculty of Vet. Med. Assiut University \\ *** Fellow, Assiut University Hospitals \\ Email: yasser wafy 2014@yahoo.com
}

\section{ABSTRACT}

Received at: $26 / 8 / 2014$

Accepted: 19/10/2014
A total of 60 random samples of yoghurt and feta cheese (30 of each ) were collected from Food Department in Assiut University hospitals from July, to October, 2013 for estimation the counts and identification of total yeasts and moulds in yoghurt and feta cheese. In yoghurt only 14 samples (46.67\%) contaminated with yeasts and moulds and their counts / gram are ranged from 2.1 $\times 10^{1}$ to $1.1 \times 10^{3}$ with an average count of $4.76 \times 10^{2} / \mathrm{gram}$. The highest frequency distribution was $6(42.86 \%)$ lied within the range of $>10^{2}$. The isolates belong to genera Aspergillus 3 (12.00\%), Penicillium 1 (4.00\%), Geotrichum 12 (48.00\%) and Monilielle $9(36.00 \%)$. In feta cheese only 8 (26.67\%) from 30 samples contaminated with yeasts and moulds and counts / gram are ranged from $2.4 \times 10^{1}$ to $1.5 \times 10^{3}$ with an average count of $2.79 \times 10^{2} /$ gram. The highest frequency distribution was $4(50 \%)$ lied within the range of $>10^{2}$. The isolates belong to genera Aspergillus 2 (13.33\%), Penicillium 1 (6.67\%), Geotrichum 7 (46.67\%) and Monilielle 5(33.33\%). The healthy importance of yeasts and moulds and methods of control are discussed.

Key words: Yoghut, feta cheese, yeast, mould.

\section{INTRODUCTION}

Yoghurt and cheese are very important foods for any person at all stages of life specially patients. So, a great deal of efforts have been made to produce and keep dairy products of good keeping quality.

Yeasts and moulds not survive pasteurization, so its presence in dairy products come mainly from reinfection of pasteurized milk during manufacture (Jordral et al., 1993) which come from the environment of factories, air, equipment, water, milk, etc.. (Jay, 1992).

The storage of any milk products in a fluctuated temperature gives a good chance for yeast and mould growth and mycotoxins production which have been associated with several cases of human poisoning of mycotoxicosis (Neal et al., 1998).

At least 200 different types of mould and yeast when growing in certain food, under suitable condition, form a substance that are toxic when eaten (Ibrahim, 2000) they are responsible for many serious diseases of liver, kidney, blood circulation system and blood forming organs (Cole and Cox, 1981), Certain species of yeast constitutes a puplic health hazard in the form of gastrointestinal disturbance, endocarditis and pulmonary infection (Wilson and Plunkett, 1965).

On the other hand, yoghurt and cheese are undesirable even when contain a few fungal numbers of yeasts and moulds as they rapidly grow in it at a wide range of temperature, $\mathrm{pH}$ and humidity resulting in objectionable changes that render the product unmarketable (Mossel, 1982).

Likewise, yeasts and moulds in milk and dairy productes might act as allergen and an irritant to human health (Karthikeyan and Dhanalaksnmi, 2010) and may be the reason for the recent gastrointestinal disease reported in individuals (Irshad et al., 2014).

In hospitals, food serving system quality control is a major management function. As the contamination of yoghurt and cheese with a wide range of yeasts and moulds constitute a great problem for food consumer, therefore this work is planned to secure the prevalence of yeasts and moulds in yoghurt and cheese serving in Assuit University hospitals.

\section{MATERIALS and METHODS}

\section{Collection and Preparation of samples}

A total of 60 random samples of yoghurt and feta cheese (30 of each) were collected in clean, dry and 
sterile containers from Food Department in Assiut University hospitals from July to October, 2013.

Each sample was put in an ice tank with thermometer to maintain temp. at $4^{0} \mathrm{C}$. The samples were dispatched to the laboratory with a minimum of delay where they were examined.

\section{Yoghurt:}

$11 \mathrm{~g}$ of the well mixed yoghurt samples were transferred into sterile flask containing $99 \mathrm{ml}$ of sterile $0.1 \%$ peptone water to obtain 1 / 10 dilution (A.P.H.A., 1985).

\section{Cheese (Fete cheese):}

11 gram of the well mixed cheese samples were transferred into sterile mortar and thoroughly mashed. $99 \mathrm{ml}$ of sterile $2 \%$ sodium citrate solution were added to obtain 1/10 dilution. Ten fold serial dilution up to $10^{-8}$ from each sample of yoghurt and cheese were prepared.
Estimation of total yeasts and moulds counts (Harrigan and McCance, 1976):

From the already prepared serial dilutions, duplicate marked plates were inoculated with one $\mathrm{ml}$ from each dilution and carefully mixed with $10-15 \mathrm{ml}$ of malt extract agar (containing $500 \mathrm{mg}$ each of chlorotetracycline $\mathrm{Hcl}$ and chloramphenicol) tempered at $45 \pm 1^{0} \mathrm{C}$. After solidification inoculated plates were incubated at $25{ }^{0} \mathrm{C}$ for 5 days of incubation to determine the degree of growth and then repeated on the fifth day. All yeasts and moulds colonies calculated and recorded.

Identification of yeast and mould gnera and species (Moubasher, 1993):

Macroscopical examination: That is carried out by naked eye or by using magnifying hand lens.

\section{Microscopical examination:}

By using the wet mount technique a triangular piece of mould colony (4-6 days).

\section{RESULTES}

Table 1: Statistical analytical results of yeasts and moulds counts / $g$ of the examined yoghurt and feta cheese samples:

\begin{tabular}{lccccccc}
\hline Type of samples & \multirow{2}{*}{$\begin{array}{c}\text { N.of } \\
\text { exam. } \\
\text { samples }\end{array}$} & $\begin{array}{c}\text { N. of +ve } \\
\text { samples }\end{array}$ & $\begin{array}{c}\text { \% of +ve } \\
\text { samples }\end{array}$ & Min. & Max. & Average \\
\hline Yoghurt & 30 & 14 & 46.67 & $2.1 \times 10^{1}$ & $1.1 \times 10^{3}$ & $4.76 \times 10^{2}$ \\
\hline Feta cheese & 30 & 8 & 26.67 & $2.4 \times 10^{1}$ & $1.5 \times 10^{3}$ & $2.79 \times 10^{2}$ \\
\hline
\end{tabular}

Table 2: Frequency distribution of the examined serving yoghurt and feta cheese samples based on their yeasts and moulds counts / g:

\begin{tabular}{lcccc}
\hline Interwals & Yoghurt & \multicolumn{2}{c}{ Feta cheese } \\
\hline & No.of +ve samples $/ 30$ & \% of +ve samples & No.of +ve samples $/ 30$ & $\%$ of +ve samples \\
\hline$>10^{1}$ & 4 & 28.57 & 3 & 37.5 \\
\hline$>10^{2}$ & 6 & 42.86 & 4 & 50 \\
\hline$>10^{3}$ & 4 & 28.57 & 1 & 12.5 \\
\hline
\end{tabular}

Table 3: Fungal genera and their $\%$ of the examined serving yoghurt and feta cheese samples:

\begin{tabular}{lcc}
\hline Fungal genera & $\%$ in Yoghurt & $\%$ in Feta cheese \\
\hline Aspergillus & $3(12.00 \%)$ & $2(13.33 \%)$ \\
\hline Penicillium & $1(4.00 \%)$ & $1(6.67 \%)$ \\
\hline Geotrichum & $12(48.00 \%)$ & $7(46.67 \%)$ \\
\hline Monilielle & $9(36.00 \%)$ & $5(33.33 \%)$ \\
\hline Total & $25(100.00)$ & $15(100.00)$ \\
\hline
\end{tabular}




\section{DISCUSSION}

The summarized results in Tables $1,2 \& 3$ showed that only $14(46.67 \%)$ samples contaminated with yeasts and moulds and their counts / $\mathrm{g}$ in yoghurt samples ranged from $2.1 \times 10^{1}$ to $1.1 \times 10^{3}$ with an average count of $4.76 \times 10^{2} \mathrm{cfu} / \mathrm{g}$. The highest frequency distribution was $6(42.86 \%)$ lied within the range of $>10^{2} \mathrm{cfu} / \mathrm{g}$. According to Egyptian Standards (1990), yoghurt must be free from yeasts and moulds, that due to its media which is a good environment for growth, multiplication and mycotoxins production.

The isolates belong to genera Aspergillus 3 (12.00\%), Penicillium 1 (4.00\%), Geotrichum $12(48.00 \%)$ and Monilielle $9(36.00 \%)$. Nearly similar results were obtained by Abuzied and Hammad (2002) and Bahout and Moustafa (2002).

The stipulated results in Tables $1,2 \& 3$ indicated that only $8(26.67 \%)$ from 30 feta cheese samples contaminated with yeasts and moulds and their counts / gram in feta cheese samples ranged from $2.4 \times 10^{1}$ to $1.5 \times 10^{3}$ with an average count of $2.79 \times 10^{2} \mathrm{cfu} / \mathrm{g}$. According to Egyptian standards (2000), cheese must be not contain more than $10 \mathrm{cfu} / \mathrm{g}$ yeasts and moulds. The highest frequency distribution was $4(50 \%)$ lied within the range of $>10^{2} \mathrm{cfu} / \mathrm{g}$.

The isolates belong to genera Aspergillus 2 (13.33\%), Penicillium 1 (6.67\%), Geotrichumb 7 (46.67\%) and Monilielle 5(33.33\%). Nearly similar results were obtained by EL-shaheer (2013) and Hegazy and Mahgoub (2013). Higher results were obtained by Salih et al. (2012).

The ability of the mould and yeast species to grow at low temperatures and their proteolytic and lipolytic activities (Besancon et al., 1992 and Jakobsen and Narvhus, 1996) may cause spoilage of food by break down their components and liberation of different acids and gases with subsequent change of their odour and flavor and become undesirable and often result in down grading of the product which lead to economic losses (Bouton and Grappin 1995; Beuvier et al., 1997 and EL-Kewaiey et al., 2014).

Likewise, yeast and mold indicator testing is extremely important for determining product freshness and quality, but the current testing process is so long that it can hold up a product's release for several days.

In general, presence of yeasts and moulds in yoghurt and feta cheese indicate their manufacturing under unsanitary condition and recontamination of pasteurized milk used in manufacturing by workers hand, equipment, utensils and containers or from dust, air and water. Fluctuated temperature given a good chance for growth and multiplication of fungi and secretes toxins which cause the harmful effect to the consumers.

\section{CONCLUSION}

In hospitals, milk and dairy products specially yoghurt and cheese are considered the main foods for patients, so that dairy products must be safe, healthy and free from any contamination, specially yeasts and moulds.

So, the following points must be taken in consideration:

Dairy products must be come from dairy processing plant which apply HACCP system in processing, packing, storage and distribution of such products.

Cooling equipment should be fitted with thermograph and cooling monitored by experience personnel.

Avoid presence of dairy products in room temperatures for long time, specially in summer.

\section{REFERENCES}

A.P.H.A. (1985): Standard methods for the examination of Dairy Productes. $15^{\text {th }}$ Ed., American Public Health Association, Washington, D.C.

Abuzied, A.S. and Hammad, A.M. (2002): Microbiological evaluation of locally produced yoghurt. J.Egypt. Vet. Med. Assoc.62,(60): 353-367.

Bahout, A.A. and Moustafa, A.H. (2002): Occurrence of fungi and aflatoxins in yoghurt marketed in Zagazig City. Assiut Vet. Med. J. 49(96): 195-203.

Besancon, X.; Smet, C.; Chabaler, C.; Rivemale, M.; Revebal, J.P.; Ratomahenine, R. and Galzy, $P$. (1992): Study of surface yeast flora of Roquefort cheese, International J. of food Microbiol. 17-9:18.

Beuvier, E.; Berthaud, K.; Cgarra, S.; Dasen, A.; Pochet, S.; Buscihon, S. and Duboz, G. (1997): Ripening and quality of Swiss-type cheese made from raw, pasteurized or micro filtered milk. International Dairy J. 7: 311-323.

Bouton, Y. and Grappin, R. (1995): Comarasion de la qualite de fromages a pate pressee cute fabriques a partir de lait cru ou microfiltre hait 75:31-44.

Cole, R.J. and Cox, R. (1981): Hand book of Toxic Fungal Metabolism. New York. Academic Press.

Egyptian standards (1990): Milk and Dairy products. Yoghrt Egyptian Organization For Standardization and quality Control. ES 6: 1000. 
Egyptian standards (2000): Milk and Dairy products. Raw milk Egyptian Organization for Standardization and quality Control. ES6: 1154.

EL-Kewaiey, I.A.; Khafaga, N.I. and Amal, A.A. (2014): Mycological quality and aflatoxin residues in some poultry meat in Damanhour. Assuit Vet. Med. J. 60 (140): 191-199.

EL-Shaheer-Y.A. (2013): Microbiological quality of locally manufactured cheese served in Assiut University hospitals. M.V. Sc. Thesis, Fac. Vet. Med., Assiut Univ., Egypt.

Harrigan, W.F. and McCance, M.F. (1976): Laboratory Methods in Food and Dairy microbiology. Academic Press, Lodon, New York, San Fracisco.

Hegazy, M.I. and Mahgoub, A.M. (2013): Microbial characterization of the Egyptian soft white cheese. Microbiol. Res. 7(20): 2205-2212.

Ibrahim, N.A. (2000): Food safety is the responsibility of every one. 1 st. Cng. food hygiene and human Health. Fac. Vet. Med., Assiut Univ., Egypt.

Irshad, M.S.; Emily, J.; Steven, S. and Khalil, K. (2014): Molecular Identification of Isolated Fungi from Unopened Containers of Greek Yogurt by DNA Sequencing of Internal Transcribed Spacer Region Pathogens, 3, 499-509.

Jakobsen, M. and Narvhus, J. (1996): Yeasts and their possible beneficial and negative effect on the quality of dairy productes. Internatonal Dairy J., 6: 755-766.
Jay, J.M. (1992): Modern Food Microbiology (4 ${ }^{\text {th }}$ ed). New York: Chapman and Hall, pp. 1-701.

Jordal, M.; Linan, E.; Acosta, I.; Gallego, C.; Rojas, F. and Bentabol, A. (1993): Mycoflora and toxigenic Aspregillus flavus in Spanish milk. International Journalof food Microbiology, 18: $171-174$.

Karthikeyan, N. and Dhanalaksnmi, B. (2010): Hygienic quality of Indian sweet milk products from different sources. Banglad J. Microbiol.; 27: $32-37$.

Mobasher, A.H. (1993): Soil fungi in Qater and other Arab countries. The Scientific and Applied Research Center, University of Qater -Doha Qater.

Mossel, D.A. (1982): Microbiology of food $3^{\text {rd }}$. The University of Utrech, The Netherland ISBN.

Neal, G.E.; Eatan, D.l.; Judah, D.J. and Verman, A. (1998): Metabolism and toxicity of aflatoxin $\mathrm{M}$, and $\mathrm{B}$, in human derived in vitro systems. Toxicol. Appl. Pharmacol. 151(1): 152-158.

Salih, A.Z.; Sulieman, E.A-M.; Elkhalifa, A.E. and Ali, O. (2012): Chemical and Microbiological characters of white cheese (Jibna beida) produced in Sudan. Dep. Food Sci. and Technol, Fac. of Engineering and Technology Univ. of Gezira Wad-Medani, Sudan2(6): 259-264. doi:10.5923/Jfp:20120206.6.11.

Wison, J.W. and Plnkett, O.A. (1965): The fungal diseases of man. Berkeley Univ. of California Press.

\section{الحالة الفطرية لبعض منتجات الالبان المستخذمة فى مستثفيات جامعة اسيوط}

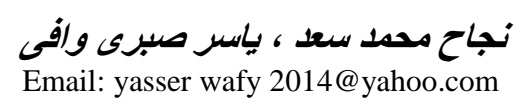

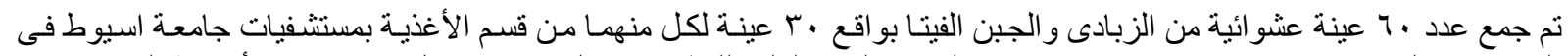

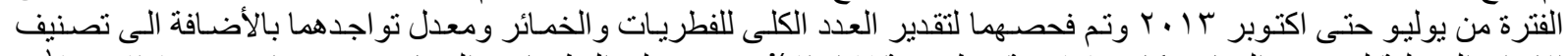

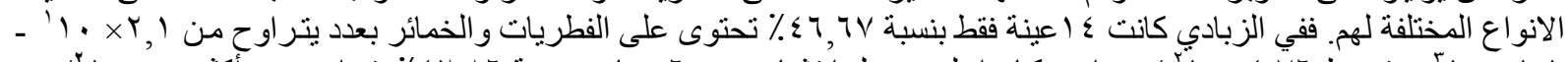

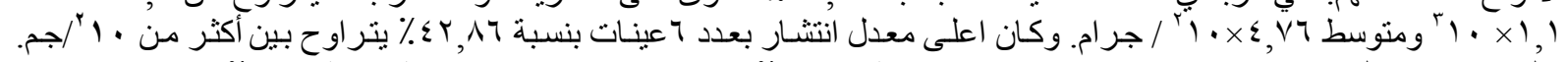

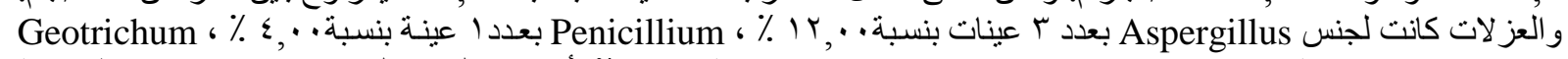

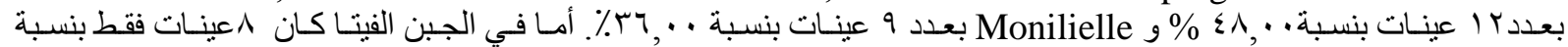

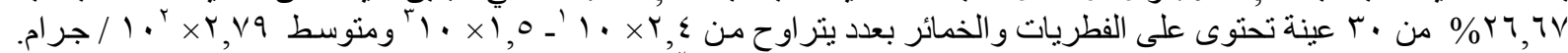

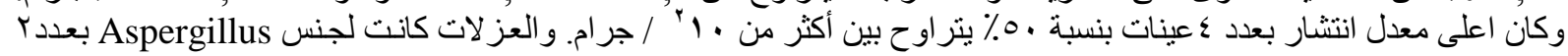

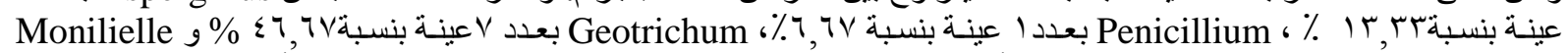

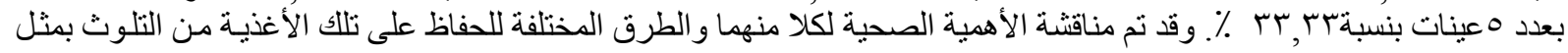
هذه الفطريات و الخمائر. 